\title{
TINJAUAN TEOLOGIS TENTANG IBLIS \\ DALAM INJIL SINOPTIK
}

\author{
Aru Banga \\ I Ketut Enoh \\ sttjaffraymakassar@yahoo.co.id
}

\begin{abstract}
ABSTRAK
Adapun tujuan karya ilmiah ini adalah: Pertama, mempelajari pandangan atau konsep Alkitab tentang iblis/setan dan roh-roh jahat dalam Injil Matius. Kedua, mempelajari pandangan atau konsep Alkitab tentang iblis/setan dan roh-roh jahat dalam Injil Markus. Ketiga, mempelajari pandangan atau konsep Alkitab tentang iblis/setan dan roh-roh jahat dalam Injil Lukas.

Untuk memperoleh data yang memadai dalam karya ilmiah ini, penulis mengadakan penelitian kepustakaan (Library research) dan media internet mengenai iblis, yang mana penelitian ini akan berpusat pada ungkapan-ungkapan ke tiga Injil Sinoptik Matius, Markus, dan Lukas dan cerita-cerita di dalamnya meyangkut kuasa jahat itu. Studi kata dan Latar Belakang ke tiga Injil Sinoptik tentang iblis, dan kuasa jahat itu akan menjadi fokus penelitian karya ilmiah ini.

Berdasarkan penguraian penulis dalam tulisan ini maka dapat ditarik kesimpulan sebagai berikut: Pertama, Dalam bagian pemahaman tentang Injil Sinoptik dijelaskan secara latar belakang tentang penulis ke tiga Injil tersebut. Kedua, Dalam bagian pemahaman Injil Sinoptik dijelaskan secara latar belakang masing-masing ketiga Injil tentang maksud dan tujuan penulis. Ketiga, Dalam bahagian pemahaman Injil Sinoptik dijelaskan tentang pengertian Injil dan Injil Sinoptik. Keempat, Dengan tegas Injil Sinoptik menjelaskan tentang Iblis. Walupun ada orang Kristen yang tidak menerima kebenaran ini. Namun tidak dapat diragukan lagi bahwa kitab Injil Sinoptik sangat jelas membicarakan Iblis dan roh-roh jahat. Kelima, Khususnya dalam konsep Injil Sinoptik sangat nyata bagaimana pekerjaan Iblis diuraikan dengan, mencobai, melalui fikiran manusia, merasuki tubuh manusia, membuat penyakit, menggunakan posisi, menggunakan waktu yang baik, serta menawarkan kemegahan dunia.
\end{abstract}

Kata Kunci: Tinjauan Teologis, Iblis, injil sinoptik. 


\section{PENDAHULUAN}

\section{Latar Belakang Masalah}

Iblis atau juga disebut setan merupakan oknum yang selalu mengacaubalaukan kehidupan manusia. Iblis senang melihat orang Kristen yang lemah imannya dan menjadikan sebagai budaknya bahkan menjadi pengikut iblis. segala macam upaya dan usaha dilakukan oleh iblis dalam sepanjang sejarah manusia yang membawa kepada kehancuran total hubungan manusia dengan Allah.

Pertama kali iblis ditulis dalam Perjanjian Lama, pada saat Allah pertama kali menciptakan manusia, yaitu Adam dan Hawa, iblis berhasil dalam pekerjaannya menggoda Hawa untuk berpaling dari Allah dengan memakan buah yang diperintahkan Allah kepada Hawa supaya tidak memakannya, tetapi iblis berhasil menipu Hawa agar memakan buah tersebut, yaitu pohon pengetahuan yang baik dan yang jahat itu. Iblis berhasil mempengaruhi Hawa agar memakan buah yang dilarang oleh Allah dengan tipu muslihat iblis akan tawaran-tawaran yang sangat menarik dari iblis kepada Hawa tentang Hawa akan menyamai dirinya dengan Allah dan memberikan seluruh isi bumi ini. Dan di dalam Injil Sinoptik dijelaskan bagaimana iblis mencobai Yesus sebanyak tiga kali dan menawarkan Dia seluruh isi bumi ini apabila Yesus menuruti perintah iblis. Ini membuktikan iblis juga dapat mencobai Yesus walaupun sebenarnya Allahlah yang menciptakan seluruh isi bumi dan bahkan Ia juga menciptakan malaikat yang tadinya pengikut Allah dan jatuh dalam dosa menjadi sosok iblis. ${ }^{1}$

Pekerjaan iblis dalam Injil Sinoptik tidak sedikit berbeda bentuk/wujudnya dibanding pekerjaan iblis di dalam Perjanjian Lama, hanya di Injil Sinoptik lebih banyak dibahas tentang Iblis dan roh-roh jahat. Dari persamaan maupun sedikit perbedaan inilah yang membawa penulis melihat wujud iblis khususnya dalam ke tiga Injil Sinoptik, dan belum ada karya ilmiah atau penulis yang membahas tentang tinjauan teologis tentang iblis dalam Injil Sinoptik, yang kiranya dapat dijadikan sebagai barang acuan.

Oleh sebab itu, penulis tertarik untuk menguraikannya dan mengangkatnya sebagai suatu karya ilmiah dengan judul: "TINJAUAN TEOLOGIS TENTANG IBLIS DALAM INJIL SINOPTIK.”

\section{Pokok Masalah}

Sesuai dengan penjelasan pada latar belakang, maka yang menjadi pokok masalah dalam karya ilmiah ini adalah: Bagaimana konsep Injil Sinoptik tentang iblis/setan dan roh-roh jahat.

${ }^{\mathrm{l}}$ Ensiklopedi Alkitab Masa kini jilid I A-L (Jakarta: Yayasan Komunikasi Bina Kasih OMF, 1992), 410. 


\section{Tujuan Karya}

Adapun tujuan karya ilmiah ini adalah: Pertama, mempelajari pandangan atau konsep Alkitab tentang iblis/setan dan roh-roh jahat dalam Injil Matius. Kedua, mempelajari pandangan atau konsep Alkitab tentang iblis/setan dan roh-roh jahat dalam Injil Markus. Ketiga, mempelajari pandangan atau konsep Alkitab tentang iblis/setan dan roh-roh jahat dalam Injil Lukas.

\section{Manfaat Karya}

Beberapa manfaat karya ilmiah adalah: Pertama, agar setiap orang Kristen dapat mengerti pekerjaan iblis berdasarkan pandangan Injil Sinoptik. Kedua, bagi karya karya ilmiah ini bermanfaat untuk menambah wawasan agar penulis dapat mengetahui cara kerjanya iblis khususnya dalam Injil Sinoptik yaitu: bagaimana pekerjaan iblis di surat Injil Matius, Markus, dan Lukas. Ketiga, untuk memenuhi persyaratan mencapai gelar sarjana Teologi.

\section{Metode Penelitian}

Untuk memperoleh data yang memadai dalam karya ilmiah ini, penulis mengadakan penelitian kepustakaan (Library research) dan media internet mengenai iblis, yang mana penelitian ini akan berpusat pada ungkapan-ungkapan ke tiga Injil Sinoptik Matius, Markus, dan Lukas dan cerita-cerita di dalamnya meyangkut kuasa jahat itu. Studi kata dan Latar Belakang ke tiga Injil Sinoptik tentang iblis, dan kuasa jahat itu akan menjadi fokus penelitian karya ilmiah ini.

\section{Batasan Karya Penulisan}

Penelitian ini difokuskan pada mempelajari pandangan Alkitab dalam Injil Sinoptik menyangkut iblis/setan dan dengan uraian tersebut dapat dijadikan sebagai bahan pemahaman Teologis.

\section{KONSEP TENTANG IBLIS}

\section{Asal -Usul Setan atau Iblis}

Setan memiliki sifat-sifat iblis. Sedikit banyaknya, sifat Iblis adalah juga sifat setan-setan. Karena iblis berdosa, mereka juga ikut berdosa. Karena Iblis di hukum oleh Allah, mereka juga ikut dihukum. Untuk mengerti sifat dan penyelewengan mereka, kita harus mengerti siapa iblis itu. 
Sungguh sangat tidak mungkin Allah yang begitu suci dapat menciptakan mahkluk yang kemudian menjadi Iblis jahanam. Ini akan langsung bertentangan dengan setiap prinsip yang benar dari Allah. Meskipun demikian, Iblis ada dan sifat-sifatnya langsung bertentangan dengan semua sifat kekudusan Allah. Jadi dari mana sebetulnya Setan berasal.

Ini merupakan cerita yang aneh dan hampir-hampir tak bisa dipercaya. Meskipun kitab Suci tidak menjelaskan kejadian itu secara terperinci, namun ada ayat-ayat yang memberi sinar terang pada misteri ini. Nampaknya seakan-akan Allah sendiri segan menceritakan tragedi yang begitu menyedihkan itu.

Penciptaan terjadi lama sekali pada masa yang lampau. Waktunya yang tepat tidak begitu penting. Tetapi yang penting untuk diingat ialah bahwa sebelum ada manusia dan benda-benda lain, Allah Tritunggal kita yang besar sudah ada. Ia adalah Allah yang tidak pernah diciptakan. Ia sudah ada tanpa awal dan akhir kekal dan abadi. Untuk tujuan kemuliaanNya sendiri, Allah melaksanakan rencana penciptaan-Nya. Semua ini terjadi "pada mulanya".

Penciptaan itu sangat mengagumkan !. Sekarang kita hanya dapat melihat dengan tidak sempurna bagian-bagian alam semesta yang mengherankan dan mengagungkan, yang diciptakan pada waktu itu. Bintang-bintang, bulan, dan matahari, serta susunan susunannya- siapa yang dapat mengerti semua itu ?. Sungguh suatu karya Allah yang agung dan luar biasa.

Alam semesta seolah-oleh terbentang tanpa batas. Dengan teratur alam semesta meakukan tugasnya, dengan setia memenuhi tujuan dari penciptanya Yang Mahakuasa. Semua bekerja dalam keserasian menurut fungsi dan susunannya.

Apakah alam semesta bekerja tanpa pengawasan?. Apakah ada kemungkinan gagal ? sementara Tuhan menanggani benda-benda, anda akhirnya juga makhluk-makhluk hidup, dapatkah sesuatu diserahkan kepada keadaan atau kepada kemungkinan adanya pembangkangan?.

Lama sebelum penciptaan, rupanya Allah menciptakan para pesuruh untuk meronda dan mengawasi seluruh ciptaan-Nya. Makhluk-makhluk itu disebut malaikat.

Adalah sesuai dengan sifat Tuhan untuk mengerjakan segala sesuatu dengan keteraturan yang sempurna. Rupa-rupanya malaikat diciptakan sebelum ada langit dan bumi, karena itu mereka sangat bergembira ketika mereka menyaksikan proses penciptaan Allah (Ayub 38 : 7). Pada waktu itu, seperti juga sekarang, para malaikat diberi tugas untuk mengawasi kekuatan-kekuatan alam.

Barangkali yang mengepalai banyak sekali makhluk-makhluk sorga ini dan yang mengawasi tugas pelayanan mereka adalah Lucifer (Yesaya 14 : 12 disebut "bintang timur")- "pembawa terang", / "inti terang", 
/"kecemerlangan", atau "penerang jalan". Kitab suci menunjukkan bahwa Lucifer mungkin yang paling berkuasa dan bijaksana dari semua makhluk Allah. Kisah Lucifer diceritakan dalam satu nubuat Yehezkiel $28: 12$ - 17:

"Hai anak manusia, ucapkanlah suatu ratapan mengenai raja Tirus dan katakanlah kepadanya : Beginilah firman Tuhan Allah, gambar dari kesempurnaan engkau, engakau penuh hikmat dan mha indah. Engkau di taman Eden, yaitu taman Allah;penuh segala batu permata berharga: yaspis merah, krisolit dan yaspis hijau, permata pirus, krisopras dan nefrit, lazurit, batu darah dan mlakit. Tempat tatahannya diperbuat dari emas dan disediakan pada hari penciptaanmu. Kuberikan tempatmu dekat kerub yang berjaga, di gunung kudus Allah engkau berada dan berjalan-jalan di tengah batu-batu yang bercahaya-cahaya. Engkau tak bercela di dalam tingkah lakumu sejak hari penciptaanmu sampai terdapat kecurangan padamu. Dengan dagangmu yang besar engkau penuh dengan kekerasan dan engkau berbuat dosa. Maka Kubuangkan engkau dari gunung Allah dan kerub yang berjaga membinasakan engkau dari tengah batu-batu yang bercahaya. Engkau sombong karena kecantikanmu, hikmatmu kaumusnahkan demi semarakmu. Ke bumi kau Kulempar, kepada raja-raja engkau Kuserahkan menjadi tontonan bagi matanya"

\section{Nama-Nama Iblis}

Didalam Alkitab ada beberapa nama dan julukan yang diberikan kepada si iblis. Nama-nama itu jelas mengatakan sifat-sifatnya. Paling sering ia disebut iblis, artinya musuh; lalu, setan atau pemfitnah. Dalam Injil sinoptik kata ini sering dipakai dalam bentuk tunggal. Dalam hal itu, kata itu tidak untuk menyebutkan si iblis, tetapi untuk menyebutkan roh-roh jahat, yaitu roh-roh yang telah jatuh ke dalam dosa, yang melakukan kehendak iblis. Seharusnya mereka disebut roh-roh jahat, bukan setan. Nama-nama lain adalah

1. Belzebul, (penghulu setan) :(Mat. 12: 24),(Luk.11:15,18,19),(Mark 3 : 22).

2. Si jahat:(Mat.13:19).

3. Si pencoba: (Mat 4:3),(Mark 1:12-13),(Luk 4:2).

4. Roh-roh jahat: (Mark. 1:26),(Luk.4:35),(Mat.8:16) ${ }^{3}$

\section{Sifat-Sifat Iblis}

Ada beberapa sifat-sifat iblis yang dapat kita catat, antara lain: Jahat, Iblis adalah musuh semua yang baik, penuh penipuan dan kejahatan yang terus berusaha merusakkan semua Allah yang baik dan benar. Ia tidak berdiri pada yang benar karena memang tidak ada kebenaran padanya karena memang ia jahat (Mat. 6:13).

\footnotetext{
${ }^{2}$ William W. Orr , Setan Ada atau tidak ?, (Bandung: Yayasan Kalam Hidup, 1970), $13-15$.

${ }^{3}$ William W.ORR,Misteri Iblis,(Bandung : Kalam Hidup)hal 24
} 
Penipu, Iblis itu licik dan penipu. Ia sombong dan tinggi hati(Mat 4:5,6). Mencobai, Dalam kejahatannya, iblis menuduh dengan tuduhan palsu dan selalu mencobai orang-orang percaya dan Tuhan Yesus sendiri(Luk.4:2). Pencuri, Dalam Luk 8:12 iblis berusaha mencuri firman Tuhan yang telah ditanamkan dalam hati manusia. ${ }^{4}$

\section{Kuasa dan Kewibawaan Iblis}

Kuasa Iblis sangat besar. Dalam Matius 4:8 dan Lukas 4:5, ia berkuasa, memperlihatkan kepada Yesus semua kerajaan dunia sekaligus. Semua orang yang belum percaya kepada Kristus dan belum lahir baru, ada dibawah kuasa Iblis dan agen-agennya. Oleh sebab semua orang yang diluar gereja Kristus adalah milik iblis. Walupun kebenaran tentang hal ini tidak disukai oleh manusia semua di dunia ini adalah dalam kuasa iblis karena iblis adalah penghulu dunia ini dan manusia adalah"anak setan", dan iblis adalah "bapaknya".

Dapat dilihat bahwa orang yang dikuasai iblis telah dibutakan rohaninya dan berada dalam hukuman Allah. Ia bagaikan orang yang sudah dipenjarakan iblis. Iblis sendiri dilukiskan sebagai orang yang kuat, rumahnya yang dipenuhi manusia yang diperalatnya. Sebelum manusia dibebaskan dari penghambaan iblis, orang kuat (iblis) harus diikat, sesudah itu barulah rumahnya dibuka (Mat.12:29;Mrk 3:27;Luk. 11:21,22).

Dalam doa Yesus untuk murid-muridNya, Kristus berdoa agar muridmuridNya dilindungi dari si jahat. Yesus tahu bahwa kuasa musuhNya itu sangat besar. ${ }^{5}$

\section{Perbedan dirasuk Setan dan dipengaruhi Pengertian dirasuk Setan}

Masalah "kerasukan setan" atau"dimiliki oleh setan" (Demon Possession) merupakan hal yang actual pada abad ini sehingga diselidiki secara serius dan diskusikan di mana-mana tempat. Profesor Bender pernah mengundang Dr. Koch untuk memberikan ceramah tentang problema kerasukan setan di Institute-nya di Freiburg. Ia juga mengundang para psikolog, teolog Katolik, dan seorang professor dari rumah sakit jiwa yang menunjukkan gejala-gejala yang susah dipahami oleh psikiatris. ${ }^{6}$

Pasien wanita itu sering tiba-tiba berteriak dan berkata bahwa ia digigit oleh suatu kekuatan yang tak kelihatan. Parut-parut terlihat pada tubuhnya. Pada saat yang lain seakan-akan ia bergulat dengan ular besar. Tanda-tanda lilitan ular sempat difoto oleh asisten dokter. Psikiatris itu menjelaskan bahwa gejala ini disebut Psyhogenic dermatography (tanda-

\footnotetext{
${ }^{4}$ Ibid., hal 22

${ }^{5}$ Pdt. Dr. E.P. Gintings, Drs. Djorelit Surbakti, Maria Br. Ginting,Okultisme,(Bandung : Bina Media Informasi) hal 2 1980, hal.47.

${ }^{6}$ Dr. Kurt Koch,Occoult ABC, Literature Mission Aglasterhausaen Inc, Germany, tahun
} 
tanda di kulit yang berasal mula dari pikiran). Pada suatu kejadian seorang perawat pernah berusaha melindungi pasien tersebut dengan memeluk pasien itu kuat-kuat. Perawat tersebut digigitnya. Kadang-kadang suara laki-laki keluar dari si pasien tersebut menyatakan mereka adalah 7 setan. Psikiatris menyebut proses disasosiasi yang tidak disadari ini dalam 7 bagian kebebasan. ${ }^{7}$

Para teolog Katolik ditanyai, bagaimana mendapat mereka tentang kasus ini? Jawabnya,"Itu kerasukan setan!"Psikiaris itu menjawab,"Itu Adalah kasus hysteria, meskipun bentuk yang macam ini belum pernah saya melihatnya. Baru sekarang ini melakukan sesuatu yang berhubungan dengan sihir dan spritisme?" Jawabnya,"Ya." Maka Dr. Koch menjawab,"Itu pasti kerasukan setan." ${ }^{8}$

Dari diskusi yang disebutkan di atas dapatlah kita ketahui bahwa masalah "kerasukan setan" itu pada dasarnya menimbulkan 2 pandangan

- Hal kerasukan setan itu memang sungguh-sungguh ada. Ada kekuatan atau kekuasaan di luar diri manusia yang menguasai dan menaklukkan manusia, yaitu kuasa iblis.

- Hal kerasukan setan itu adalah gejala kejiwaan biasa, yang menyebabkan orang tersebut berbuat aneh-aneh bukanlah oknum di luar dirinya, tetapi kekacauan jiwanya, bersumber pada dirinya sendiri. Bahkan ada teolog atau psikiatri Kristen yang berpandangan seperti ini. Lalu bagaimana mereka menjelaskan ayat-ayat Alkitab yang berbicara mengenai kerasukan setan? Jawab mereka,"itu adalah ketidak ngertian murid-murid Yesus terhadap gejala yang terjadi seperti itu, sehingga langsung berasosiasi bahwa gejala abnormal itu disebabkan oleh iblis, roh jahat itu," Umpama murid-murid Tuhan Yesus dan menulis Alkitab hidup masa kini, tentu dia akan menyatakan bahwa gejala abnormal itu adalah gejala jiwa biasa, tidak ada pengaruhnya sama sekali dengan oknum yang disebut setan itu."

Sebagai seorang Kristen yang meyakini bahwa apa yang dikatakan oleh Alkitab itu benar, maka kita mempercai bahwa hal kerasukan setan itu memang sungguh-sungguh ada. Setan dapat memilki dan merasuk seseorang sehingga orang itu menunjukkan gejala-gejala abnormal. Kalau yang tidak mempercayai adanya kerasukan setan berpendapat bahwa murid-murid Yesus dan para penulis Alkitab membedakan antara sakit fisik, jiwa dan kerasukan setan? Marilah kita melihat dari Firman Allah :

Alkitab Wahyu Allah itu mengatakan dengan jelas akan adanya kerasukan setan. Contoh dalam: Markus 1:32,34; dalam ayat ini Markus memberikan komentar tentang apa yang Yesus perbuat terhadap orangorang yang datang kepada-Nya. Dalam 2 ayat tersebut kita dapat membaca bahwa menderita sakit penyakit dan kerasukan setan adalah dua hal yang

\footnotetext{
${ }^{7}$ Ibid

${ }^{8}$ Ibid.
} 
berbeda, maka itu disebutkan: di samping Yesus menyembuhkan banyak orang yang menderita sakit penyakit Yesus juga mengusir setan-setan. Markus 7:31-35 Dan Markus 9:14-29; Dalam 2 perikop Alkitab ini ada 2 macam keadaan sakit : Dalam Markus 7:31-35 disebutkan sejenis penyakit karena kerasukan dan gangguan pada organ tubuh sehingga membuat orang itu tuli dan gagap. Yesus menyembuhkan dengan cara memasukkan jariNya ke telinga orang itu dan meraba lidah orang itu (ayat 33) sambil berkata, "terbukalah!" Dalam Markus 9:14-29 disebutkan adanya seorang anak yang kerasukan setan sampai bisu. Yesus menyembuhkan anak itu dengan cara mengusir roh jahat itu keluar. Setelah roh jahat keluar sembuhlah anak itu, dengan kewibawaan-Nya Yesus tadi mengatakan, “... keluarlah (Yunani exerchomai, artinya larilah, terhamburlah) dari anak ini..." (ayat25). Markus 16:17-18; Sebelum Yesus naik ke surga, Ia memberikan kuasa kepada murid-murid-Nya. Sebagai tanda bahwa Yesus Kristus menyertai murid-murid-Nya, maka mereka akan mengusir (ekballo) setan-setan keluar dari manusia demi nama Tuhan Yesus Kristus. Dalam ayat-ayat ini mengusir setan dengan menyembuhkan sakit penyakit. Matius 10:1-8; Dalam perikop ini disebutkan bahwa Yesus memanggil murid-murid-Nya, memberi mereka kuasa untuk mengusir roh jahat dan menyembuhkan segala penyakit (ayatl). Yesus memerintahkan kepada rasul-rasul-Nya, " Sembuhkanlah orang sakit... usirlah setan-setan..."(ayat 8). Dari perikop ini kita dapat melihat dengan jelas bahwa "menyembuhkan orang sakit" dibedakan dengan "mengusir roh-roh jahat atau setan-setan." Perkataan "mengusir" dalam ayat 1 dan ayat 8 sebenarnya berasal dari bahasa Yunani ekballo berarti: melemparkan keluar dari, menghalau dari, mengambil dengan paksa dari. ${ }^{9}$

Dari ayat ini dapatlah dipahami bahwa iblis atau setan-setan itu dapat mendiami, memilki dan merasuk manusia. Roh jahat itu mempertahankan miliknya mati-matian, maka untuk dapat disembuhkan yang sesungguhnya, setan-setan itu harus dipaksa keluar dari dalam orang yang dirasuknya, oleh kuasa Yesus Kristus yang lebih besar dari kegelapan kuasa itu.

\section{Pengertian dipengaruhi Setan}

Di pengaruhi tidaklah berarti dirasuk setan dipengaruhi berarti diganggu tetapi tidak dirasuk. Kata dirasuk artinya memasuki atau Iblis memasuki tubuh seseorang. Contoh pada Yesus dan Petrus dipengaruhi Iblis: Matius 16:13-28; mencatat sebuah percakapan yang menggambarkan upaya Iblis untuk mempengaruhi Kristus melalui kata-kata seorang sahabat. Hal itu terjadi menjelang akhir dari kehidupan Yesus di tengah masyarakat selama tiga tahun. Petrus, seorang murid yang setia, telah membuat suatu pengakuan besar, "Engkau adalah Mesias, Anak Allah yang

\footnotetext{
${ }^{9}$ W.E, Vine, Expository Of New Testament Word, Zondervan Publishing House, Michigan, tahun 1952, hal.340.
} 
hidup!" (ayat 16). Yesus memujinya. Namun, tatkala Dia "mulai mengatakan kepada murid-murid-Nya bahwa Ia harus pergi ke Yerusalem dan menanggung banyak penderitaan ..., lalu dibunuh dan dibangkitkan pada hari ketiga" (ayat 21), Petrus sangat terkejut. Bagaimana mungkin Allah yang hidup membiarkan hal ini terjadi pada Putra-Nya yang tidak berdosa? Oleh karena itu Petrus "menarik Yesus ke samping dan menegur Dia, katanya: "Tuhan, kiranya Allah menjauhkan hal itu! Hal ini sekali-kali takkan menimpa Engkau" (ayat 22).

Penulis yakin Petrus bermaksud baik. Ia mengasihi Yesus. Ia yakin bahwa Gurunya adalah Raja -- Mesias yang dijanjikan, yang akan segera membangun kerajaan-Nya di muka bumi ini. Oleh karena itu, ia pasti sangat terkejut dengan tanggapan keras Kristus, "Enyahlah Iblis. Engkau suatu batu sandungan bagi-Ku, sebab engkau bukan memikirkan apa yang dipikirkan Allah, melainkan apa yang dipikirkan manusia" (ayat 23). Betapa berbedanya dengan ucapan-Nya beberapa saat sebelumnya! Bukannya memuji Petrus, Yesus justru menegurnya dengan keras, bahkan menyebutnya sebagai "Iblis". Tanpa sadar Petrus telah menjadi alat Iblis untuk sebaik mungkin mencegah Yesus menuju ke kayu salib. ${ }^{10}$

\section{PEKERJAAN IBLIS DAN SIKAP ORANG PERCAYA TERHADAP IBLIS}

\section{Pekerjaan Iblis Dalam Injil Sinoptik \\ Injil Markus}

Iblis Merasuki Orang

Ada tiga ciri yang menjadi kondisi dari seorang yang kerasukan setan, yakni: pertama, mencelakakan hidup orang lain (Markus 5:3). Karena itu, ia harus diikat namun tidak ada seorangpun yang sanggup mengikatnya sekalipun dengan rantai sehingga ia harus diusir pergi, jauh dari tempat pemukiman penduduk dan tempat yang dianggap tepat adalah kuburan; kedua, mencelakakan dirinya sendiri (Markus 5:5); ketiga, orang yang kerasukan setan mempunyai derajat lebih rendah bahkan dibandingkan dengan seekor binatang peliharaanpun derajatnya masih jauh lebih rendah maka dapatlah dikatakan orang yang kerasukan setan tak ubahnya seperti binatang liar yang terbuang karena tidak ada seorangpun yang dapat mengikatnya, menjinakkannya dan ia berkeliaran siang-malam. ${ }^{11}$

\footnotetext{
${ }^{10}$ Martin R. De Haan II, Iblis Di dalam Kegelapan (Yokyakarta : Yayasan Gloria), 2135.

${ }^{11} \mathrm{H}:\lfloor 20060312 . h t m$.
} 
Iblis Menawan Orang yang Belum Bertobat

Mereka melakukan semua yang dapat menawan setiap orang yang belum bertobat di bawah kuasa Setan. Ini adalah salah satu alasan bahwa dengan demikian manusia tidak mungkin mengalami pertobatan sejati diluar intervensi Allah dalam kehidupan orang itu (band. Markus 10:2627). ${ }^{12}$

Roh-Roh jahat Membangkitkan yang Jahat

Pekerjaan roh-roh jahat itu semata-mata hanyalah melakukan kejahatan, dan mereka membangkitkan hal-hal yang jahat dalam hati manusia (Markus 5:2). ${ }^{13}$

Iblis Merusak Pikiran

Mereka merusak pikiran orang sehingga orang itu menjadi gila (Markus 5:4,5). ${ }^{14}$

Iblis Mencobai Yesus di Padang Gurun

Namun, tampaknya musuh Allah mengerahkan segenap tenaga dengan berulang kali berusaha mencegah Yesus melakukan pengorbanan yang sempurna. Itulah tujuannya ketika ia dan Yesus, dengan perjanjian ilahi, saling berhadapan di padang gurun. Setelah menggambarkan pembaptisan Yesus, Markus berkata, "Segera sesudah itu Roh memimpin Dia ke padang gurun. Di padang gurun itu Ia tinggal empat puluh hari lamanya, dicobai Iblis" (Markus 1:12-13)..$^{15}$

Iblis Memanfaatkan Yudas Iskariot untuk Membunuh Yesus

Pada sisi tanggungjawab manusia, bagi Markus sudah jelas bahwa Yudas Iskariot memang harus dipersalahkan, karena ia, dalam narasi Markus, memang ambil bagian di dalam persekongkolan para pemimpin Yahudi untuk membunuh Yesus. Di sini Yudas Iskariot terlibat tindakan kriminal berkomplot dengan orang-orang yang mau membunuh Yesus. Yudas tentu saja sudah tahu setidaknya dari pemberitahuan Yesus sendiri (sampai tiga kali) bahwa Yesus akan disengsarakan dan dijatuhi hukuman mati oleh para pemimpin Yahudi, dan akan disalibkan oleh tangan bangsa lain. Dalam studinya tentang Yudas, William Klassen menyatakan bahwa keterlibatan Yudas di dalam penangkapan Yesus dimaksudkan Yudas supaya Yesus dan para pemimpin Yahudi dapat bertemu, dan di dalam pertemuan itu mereka dapat mewawancarai Yesus mengenai visi dan misi pembaharuannya, dan Yesus juga dapat diyakinkan akan perlunya menempuh cara-cara tradisional dalam melakukan pembaruan kehidupan bangsa Yahudi. Dengan kata lain, Yudas Iskariot, dengan tindakannya menyerahkan Yesus, bermaksud menghasilkan titik-titik temu antara

\footnotetext{
${ }^{12}$ Dr.R.L. Hymers, Jr. "khotbah" diakses tanggal 25 mei 2008; tersedia di http://www.realconversion.com.

${ }^{13}$ www.Solar-Aid.org.

${ }^{14}$ Ibid.

${ }^{15}$ webmaster@sabda.org.
} 
pandangan Yesus dan pandangan para pemimpin Yahudi melalui percakapan bersama.[1] Jelas, menyangkut narasi Markus, Klassen keliru, sebab para pemimpin Yahudi memperalat Yudas bukan dengan maksud supaya dapat bertemu Yesus dan mewawancarainya, tetapi untuk membunuhnya; hal ini ditegaskan Markus sampai dua kali (Mrk 3:6; 14:12).[2]

Adapun adegan penangkapan Yesus di Taman Getsemani dengan jelas dilukiskan Markus, di dalam mana Yesus menegaskan kembali bahwa kejadian ini adalah untuk menggenapi apa yang tertulis dalam Kitab Suci (Mrk 14:49b). Dari adegan ini, lahir sebutan terkenal "ciuman Yudas", ciuman yang membawa maut dari orang yang menyerahkan diri Yesus kepada para pemimpin Yahudi. ${ }^{16}$

Iblis Mempengaruhi Moral

Keadaan moral mereka sama seperti penghulu mereka, yaitu jahat dan bejat. Keadaan mereka berlawanan dengan para malaikat Allah yang tidak berdosa. Contohnya Roh-Roh Jahat Mempengaruhi Anak-Anak yang Masih Kecil. Kekejian moral roh-roh jahat itu ditunjukkan dalam Alkitab melalui pengaruh-pengaruh yang berbahaya yang di derita oleh korban-korban mereka (Markus 1:26). ${ }^{17}$

Kerasukan setan dapat terjadi dengan banyak cara, dan permulaan serangan yang sering kali sukar diusut. Tidak jarang anak-anak menjadi korban roh-roh jahat (Markus 9:21); kami telah melihat sejumlah kasus tentang anak-anak yang masih kecil yang menunjukkan gejala bahwa mereka dikuasai roh jahat. ${ }^{18}$

\section{Iblis Tidak Dapat Mengusir Iblis}

Markus 3:23, Yesus memanggil mereka, lalu berkata kepada mereka dalam perumpamaan: "Bagaimana Iblis dapat mengusir Iblis?

Iblis Mengambil Firman yang Ditaburkan

Markus 4:15, Orang-orang yang di pinggir jalan, tempat firman itu ditaburkan, ialah mereka yang mendengar firman, lalu datanglah Iblis dan mengambil firman yang baru ditaburkan di dalam mereka.

Iblis Mempengaruhi Pikiran Petrus

Markus 8:33, Maka berpalinglah Yesus dan sambil memandang murid-murid-Nya Ia memarahi Petrus, kata-Nya: "Enyahlah Iblis, sebab engkau bukan memikirkan apa yang dipikirkan Allah, melainkan apa yang dipikirkan manusia."

\footnotetext{
${ }^{16} \mathrm{H}: \backslash$ Iblis dlm luk. 5 htm.

${ }^{17}$ Ibid Scan Balawin,Permainan Iblis (Bandung: Kalam Hidup), 26.

${ }^{18}$ A. Jhon Mcmillan, Perjuangan Melawan Kuasa Kegelapan, (Malang: Gandum Mas,
} 1984), 68. 


\section{Yesus Mengusir Setan}

(Mark.16:9) Setelah Yesus bangkit pagi-pagi pada hari pertama minggu itu, Ia mula-mula menampakkan diri-Nya kepada Maria Mahdalena. Dari padanya Yesus pernah mengusir tujuh setan.

Menurut teologi Markus: bahwa Yesus dapat dicobai, tetapi Yesus yang dicobai tidak akan jatuh ke dalam dosa, dan iblis juga tidak dapat mengusir iblis, iblis juga bisa mengambil Firman yang ditaburkan bagi orang yang mendengarkan Firman, iblis memang memiliki kuasa tetapi tidak dapat mengalahkan kuasa Yesus.

\section{Injil Matius}

\section{Iblis Mencobai Melalui Kemegahan Dunia}

Iblis tahu apa yang menjadi keinginan manusia, itulah sebabnya setan selalu menggunakan semua kemegahan dunia untuk menggoda manusia. Tuhan Yesus tahu akal licik si iblis sehingga Tuhan Yesus tidak jatuh dalam cobaan di padang gurun (Matius 4:1-0). ${ }^{19}$

Iblis Mencobai Melalui Kelemahan Manusia

Iblis datang untuk mencobai Yesus pada saat yang tepat, yakni pada saat Tuhan Yesus lapar setelah berpuasa empat puluh hari empat puluh malam. Iblis datang di saat manusia berada dalam keadaan yang paling lemah dan berputus asa. ${ }^{20}$

Iblis Memutarbalikkan Fakta Kebenaran Firman Tuhan

Matius 4:1-1l mengisahkan bagaimana iblis mencobai Yesus dengan beberapa pernyataan, "seperti ada tertulis" (4:6). Fakta ini memberitahukan kepada kita bahwa iblis dan para pengikutnya, para 'anti-Kristus' juga mempelajari Alkitab dengan tujuan mengkritik dan menunjukkan kepada anak-anak Tuhan bahwa Alkitab tidak memiliki otoritas apa-apa, namun hanya sekedar buku biasa yang sedikit istimewa atau bahkan tidak istimewa sama sekali.

Ketahuilah jika semangat orang percaya dalam mempelajari Alkitab dan mempelajari bagaimana metode iblis untuk menyerang Alkitab dan iman Kristen tidak lebih besar dari semangat iblis 'mencari-cari' cara menanamkan image bahwa Alkitab penuh dengan dongeng dan kesalahan, maka sudah pasti akan banyak jatuh korban di dalam barisan prajurit Kristus. $^{21}$

\section{Iblis Mempengaruhi Pikiran Petrus}

Matius 16:13-28 mencatat sebuah percakapan yang menggambarkan upaya Iblis untuk mempengaruhi Kristus melalui kata-kata seorang sahabat. Hal itu terjadi menjelang akhir dari kehidupan Yesus di tengah

\footnotetext{
${ }^{19}$ Ibid.

20 "Ringakasan Khotbah, di akses tanggal 25 mei 2008 : tersedia di http://www. Griis. Org / ringkasan khotbah / 2004 / 20040627. htm.

${ }^{21}$ F. Budi Hardiman, Filsafat Modern Dari Machiavelli sampai Nietzsche. (Jakarta: PT Gramedia Pustaka Utama, 2004), 110.
} 
masyarakat selama tiga tahun. Petrus, seorang murid yang setia, telah membuat suatu pengakuan besar, "Engkau adalah Mesias, Anak Allah yang hidup!" (ayat 16). Yesus memujinya. Namun, tatkala Dia "mulai mengatakan kepada murid-murid-Nya bahwa Ia harus pergi ke Yerusalem dan menanggung banyak penderitaan ..., lalu dibunuh dan dibangkitkan pada hari ketiga" (ayat 21), Petrus sangat terkejut. Bagaimana mungkin Allah yang hidup membiarkan hal ini terjadi pada Putra-Nya yang tidak berdosa? Oleh karena itu Petrus "menarik Yesus ke samping dan menegur Dia, katanya: "Tuhan, kiranya Allah menjauhkan hal itu! Hal ini sekali-kali takkan menimpa Engkau“" (ayat 22).

Saya yakin Petrus bermaksud baik. Ia mengasihi Yesus. Ia yakin bahwa Gurunya adalah Raja -- Mesias yang dijanjikan, yang akan segera membangun kerajaan-Nya di muka bumi ini. Oleh karena itu, ia pasti sangat terkejut dengan tanggapan keras Kristus, "Enyahlah Iblis. Engkau suatu batu sandungan bagi-Ku, sebab engkau bukan memikirkan apa yang dipikirkan Allah, melainkan apa yang dipikirkan manusia" (ayat 23). Betapa berbedanya dengan ucapan-Nya beberapa saat sebelumnya! Bukannya memuji Petrus, Yesus justru menegurnya dengan keras, bahkan menyebutnya sebagai "Iblis". Tanpa sadar Petrus telah menjadi alat Iblis untuk sebaik mungkin mencegah Yesus menuju ke kayu salib. ${ }^{22}$

\section{Iblis Mencobai Tuhan Yesus Dengan Bujukan}

Matius 4:1-11, Yesus merasa lemah dan lapar ketika iblis mencobaiNya untuk menyalah-gunakan kuasa-Nya dengan mengubah batu-batu menjadi roti. Kemudian setan mencobai Dia agar Dia mengelak dari sengsara salib dan setan juga mencobai Yesus untuk menaikkan diri-Nya sendiri akan tetapi pada setiap kesempatan bujukan setan itu Yesus mengatakan "Tidak" dan Dia memilih untuk tetap setia kepada Allah dan Rencana-Nya. Akhirnya setan dikalahkan dan pergi. ${ }^{23}$

\section{Iblis Mencobai Dengan Iming-Iming}

Matius 4:9-11. dan berkata kepada-Nya: "Semua itu akan kuberikan kepada-Mu, jika Engkau sujud menyembah aku." Maka berkatalah Yesus kepadanya: "Enyahlah, Iblis! Sebab ada tertulis:Engkau harus menyembah Tuhan, Allahmu, dan hanya kepada Dia sajalah engkau berbakti!" Lalu Iblis meninggalkan Dia, dan lihatlah, malaikat-malaikat datang melayani Yesus". ${ }^{24}$

\footnotetext{
${ }^{22}$ Martin R. De Haan II, Iblis Di dalam Kegelapan (Yokyakarta : Yayasan Gloria), 2135.

23 “5. Gayahidup Penginjil", diakses tanggal 25 mei 2008 ; tersedia di http:// www.dci.org.uk.

${ }^{24}$ By Dr. Paul Sene, Membuka Topeng Strategi Musuhmu. Diakses 24 mei 2008; tersedia di http:// H Iblis dalam markus. Htm.
} 
Iblis Masuk ke Dalam Babi Atas Izin Allah

Bahkan yang lebih menyolok ialah kenyataan bahwa Yesus mengzinkan roh-roh jahat itu masuk ke dalam sekawanan babi yang sedang mencari makan di lereng sebuah bukit "tidak jauh dari mereka itu" (Matius 8:30). Maka babi itu lalu terjunlah dari tepi jurang ke dalam danau, dan mati tenggelam. ${ }^{25}$

Iblis Menghasut Raja Herodes

Pada waktu kelahiran Juruslamat, Iblis mengahasut Raja Herodes untuk melakukan tindakan yang kejam sekali, yaitu membunuh Bayi Raja itu (Matius 1:16-18). ${ }^{26}$

\section{Yesus Mengusir Iblis}

Matius 4:10, Maka berkatalah Yesus kepadanya: "Enyahlah, Iblis! Sebab ada tertulis: Engkau harus menyembah Tuhan, Allahmu, dan hanya kepada Dia sajalah engkau berbakti!"

Iblis Tidak Dapat Mengusir Iblis

Matius 12:26, Demikianlah juga kalau Iblis mengusir Iblis, iapun terbagi-bagi dan melawan dirinya sendiri; bagaimanakah kerajaannya dapat bertahan?

\section{Iblis Menabur Benih Lalang}

Matius 13:39, Musuh yang menaburkan benih lalang ialah Iblis. Waktu menuai ialah akhir zaman dan para penuai itu malaikat.

Iblis Dimasukkan ke Dalam Api

Matius 25:41, Dan Ia akan berkata juga kepada mereka yang di sebelah kiri-Nya: Enyahlah dari hadapan-Ku, hai kamu orang-orang terkutuk, enyahlah ke dalam api yang kekal yang telah sedia untuk Iblis dan malaikatmalaikatnya.

Murid-Murid Tuhan Yesus Diberikan Kuasa Mengusir Setan

(Mat. 10:8) Sembuhkanlah orang sakit ; bangkitkanlah orang mati ; tahirkanlah orang kusta ; usirlah setan-setan. Kamu telah memperolehnya dengan Cuma-Cuma, karena itu berikanlah Cuma-Cuma.

Jadi, menurut teologi Matius bahwa pekerjaan iblis terjadi atas seizin Allah, tanpa seizin Allah, iblis tidak dapat bekerja atau mempengaruhi, misalkan iblis mempengaruhi pikiran Petrus iblis memasuki babi. Iblis tidak dapat mengusir iblis dan Yesus lebih besar kuasanya daripada iblis.

\section{Injil Lukas}

Iblis Memanfaatkan Waktu

Dalam Injil Lukas, dilaporkan bahwa setelah Iblis gagal mencobai Yesus, ia mundur daripada-Nya dan "menunggu waktu yang baik" (Lukas

\footnotetext{
${ }^{25}$ Scan Balawin, Permainan Iblis (Bandung: Kalam Hidup), 13.

${ }^{26}$ Ibid., 30.
} 
4:13). Waktu yang baik ini tiba ketika Kisah Sengsara akan dimulai, yaitu ketika Iblis masuk ke dalam Yudas Iskariot. ${ }^{27}$

Iblis Membuat Penyakit

Iblis juga dapat mendatangkan penyakit kepada orang-orang (Lukas 9:37-42). Maksudnya bukanlah setiap penyakit datangnya dari roh-roh jahat, tetapi ada juga penyakit-penyakit yang dibawa oleh Iblis atau roh jahat kepada manusia (Lukas 13:16). ${ }^{28}$

\section{Roh-Roh jahat Merasuki Orang}

Lukas 11:24-26 "Apabila roh jahat keluar dari manusia, iapun mengembara ke tempat-tempat yang tandus mencari perhentian, dan karena ia tidak mendapatnya, ia berkata: Aku akan kembali ke rumah yang telah kutinggalkan itu. ${ }^{25}$ Maka pergilah ia dan mendapati rumah itu bersih tersapu dan rapih teratur. ${ }^{26}$ Lalu ia keluar dan mengajak tujuh roh lain yang lebih jahat dari padanya, dan mereka masuk dan berdiam di situ. Maka akhirnya keadaan orang itu lebih buruk dari pada keadaannya semula. ${ }^{29}$

Iblis Dilambangkan Sebagai ular dan Kalajengking

Lukas 10:19 Sesungguhnya Aku telah memberikan kuasa kepada kamu untuk menginjak ular dan kalajengking dan kuasa untuk menahan kekuatan musuh, sehingga tidak ada yang akan membahayakan kamu. Ular dan kalajengking adalah kekuatan musuh. Berbahaya bagi kita. Tidak mungkin seorang anak meminta sesuatu yang baik lalu dikasih yang berbahaya oleh bapanya. ${ }^{30}$

\section{Iblis Membuat Orang Menjadi bisu}

Lukas 11:14 Pada suatu kali Yesus mengusir dari seorang suatu setan yang membisukan. Ketika setan itu keluar, orang bisu itu dapat berkatakata.

\section{Iblis Menjadi Beelzebul (Penghulu Setan)}

Lukas 11:14-15Dari 100an orang ini, ada juga yang tidak setuju. Tidak heran karena dari 12 murid Yesus saja, ada 1 Yudas. Beelzebul artinya penghulu setan. Jadi orang yang bisa sembuh ini belum cukup bagi mereka; mereka masih minta tanda. Sudah ada mujizat masih minta tanda. Sudah ditolong masih minta tanda. Israel dengan Laut Terbelah pun, Musa masih mau dibunuh. Paulus berkata, aku puas di dalam Kristus. Puas dengan apa yang ada. ${ }^{32}$

Iblis Menjatuhkan Moral

Lukas 4:35, Kedagingan yang kotor dan kepuasan yang berdasarkan hawa nafsu adalah akibat dari penguasaan roh jahat atas pribadi manusia.

\footnotetext{
${ }^{27} \mathrm{H}: \backslash$ Iblis dlm Luk.5 htm.

${ }^{28} \mathrm{H}: \backslash$ Iblis dlm Lukas 7. htm.

${ }^{29}$ Ibid "Pola Iblis [043]". Diakses 25 mei 2008; tersedia di http://www.logon.org dan http://www.ccg.org.

${ }^{30}$ Ibid.

${ }^{31}$ Ibid.

${ }^{32}$ Ibid.
} 
Roh-roh jahat itu banyak sekali menguasai setiap orang moralnya sudah jatuh, yang menyerahkan dirinya kepada dosa yang keji. ${ }^{33}$

\section{Iblis Mencobai Yesus}

Lukas 4:2, Di situ Ia tinggal empat puluh hari lamanya dan dicobai Iblis. Selama di situ Ia tidak makan apa-apa dan sesudah waktu itu Ia lapar.

Iblis Mengambil Firman di Hati Mereka

Lukas 8:12, Yang jatuh di pinggir jalan itu ialah orang yang telah mendengarnya; kemudian datanglah Iblis lalu mengambil firman itu dari dalam hati mereka, supaya mereka jangan percaya dan diselamatkan.

\section{Iblis Jatuh Seperti Kilat dari Langit}

Lukas 10:18, Yang jatuh di pinggir jalan itu ialah orang yang telah mendengarnya; kemudian datanglah Iblis lalu mengambil firman itu dari dalam hati mereka, supaya mereka jangan percaya dan diselamatkan.

Iblis Tidak Dapat Mengusir Iblis

Lukas 1l:18, Jikalau Iblis itu juga terbagi-bagi dan melawan dirinya sendiri, bagaimanakah kerajaannya dapat bertahan? Sebab kamu berkata, bahwa Aku mengusir setan dengan kuasa Beelzebul.

\section{Perempuan Delapan Belas Tahun diikat oleh Iblis}

Lukas 13:16, Bukankah perempuan ini, yang sudah delapan belas tahun diikat oleh Iblis, harus dilepaskan dari ikatannya itu, karena ia adalah keturunan Abraham?"

Iblis Masuk ke Dalam Yudas

Lukas 22:3, Maka masuklah Iblis ke dalam Yudas, yang bernama Iskariot, seorang dari kedua belas murid itu.

Iblis Menuntut untuk Menampi

Lukas 22:31, Simon, Simon, lihat, Iblis telah menuntut untuk menampi kamu seperti gandum.

Murid-Murid Tuhan Yesus Diberi Kuasa Mengusir Setan

"Sesungguhnya Aku telah memberikan kuasa kepada kamu untuk menginjak ular dan kala jengking dan kuasa untuk menahan kekuatan musuh, sehingga tidak ada yang membahayakan kamu",(Luk. 10 : 19). Menurut Lukas: iblis, dapat mengambil firman di hati orang percaya, sesama iblis tidak dapat saling mengusir dan kuasa Allah lebih besar daripada Iblis.

\section{Cara Menghadapi Iblis}

\section{Bagaimana Pencobaan Iblis Bekerja}

Adalah berguna jika kita mengetahui bahwa Iblis bisa diramalkan sepenuhnya. Dia telah memakai strategi dan tipuan-tipuan kuno yang sama semenjak Penciptaan. Semua pencobaan mengikuti pola yang sama. Itulah sebabnya Paulus berkata, "Kita tahu apa maksudnya" (2Korintus 2:11). Dari

\footnotetext{
${ }^{33}$ Scan Balawin,Permainan Iblis (Bandung : Kalam Hidup), 26.
} 
Alkitab kita mengetahui bahwa proses pencobaan mengikuti empat langkah, yang dipakai Iblis baik terhadap Adam dan Hawa maupun terhadap Yesus.

Pada langkah pertama, Iblis mengenali suatu KEINGINAN di dalam diri Anda. Mungkin keinginan yang berdosa, seperti keinginan untuk membalas dendam atau untuk menguasai orang lain, atau mungkin keinginan yang logis dan normal, seperti keinginan untuk dikasihi dan dihargai atau untuk merasakan kesenangan. Pencobaan dimulai ketika Iblis mengusulkan (dengan suatu pemikiran) agar Anda menyerah pada sebuah keinginan jahat, atau agar Anda memenuhi suatu keinginan yang logis dengan cara yang salah atau pada waktu yang salah. Sadarlah selalu akan jalan pintas. Hal-hal tersebut sering kali merupakan pencobaan! Iblis berbisik, "Kamu layak mendapatkannya! Kamu harus memilikinya sekarang! Itu akan mengasyikkan ... menyenangkan ... atau membuatmu merasa lebih baik." Kita mengira pencobaan berada di sekeliling kita, tetapi Allah berfirman bahwa pencobaan dimulai dari dalam diri kita. Jika Anda tidak memiliki keinginan batin, pencobaan tidak bisa menarik perhatian Anda. Pencobaan selalu berawal dari dalam pikiran Anda, bukan dari keadaan. Yesus mengatakan, "Sebab dari dalam, dari hati orang, timbul segala pikiran jahat, percabulan, pencurian, pembunuhan, perzinahan, keserakahan, kejahatan, kelicikan, hawa nafsu, iri hati, hujat, kesombongan, kebebalan. Semua hal-hal jahat ini timbul dari dalam." (Markus 7:21-23) Yakobus memberi tahu kita bahwa ada "hawa nafsumu yang saling berjuang di dalam tubuhmu?" (Yakobus 4:1).

Langkah kedua ialah KERAGUAN. Iblis berusaha membuat Anda meragukan apa yang telah Allah firmankan tentang dosa: Apakah hal tersebut benar-benar salah? Apakah Allah benar-benar melarang kita melakukannya? Apakah Allah bukan memaksudkan larangan ini untuk orang lain atau untuk waktu yang lain? Tidakkah Allah ingin agar aku bahagia? Alkitab memperingatkan, "Waspadalah, hai saudara-saudara, supaya di antara kamu jangan terdapat seorang yang hatinya jahat dan yang tidak percaya oleh karena ia murtad dari Allah yang hidup." (Ibrani 3:12).

Langkah ketiga ialah TIPU DAYA. Iblis tidak mampu mengatakan yang sebenarnya dan disebut "bapa segala dusta" (Yohanes 8:44). Segala sesuatu yang Iblis katakan kepada Anda tidaklah benar atau hanya separuh benar. Iblis menawarkan dustanya untuk menggantikan apa yang telah Allah katakan di dalam Firman-Nya. Iblis mengatakan, "Kamu tidak akan mati. Kamu akan menjadi lebih bijaksana seperti Allah. Kamu bisa melakukannya dan lolos dengan selamat. Tidak seorangpun akan tahu. Itu akan memecahkan masalahmu. Selain itu, semua orang juga melakukannya. Itu hanyalah sebuah dosa kecil." Tetapi melakukan sebuah dosa kecil adalah bagaikan sedang hamil muda: Pada akhirnya ia akan kelihatan dengan sendirinya. 
Langkah keempat ialah KETIDAKTAATAN. Pada akhirnya Anda bertindak berdasarkan pikiran yang selama ini Anda timbang-timbang di dalam benak Anda. Apa yang mulanya merupakan sebuah gagasan kemudian muncul dalam perbuatan. Anda menyerah pada apapun yang menarik perhatian Anda. Anda mempercayai dusta Iblis dan jatuh ke dalam perangkap yang diperingatkan oleh Yakobus: "Tetapi tiap-tiap orang dicobai oleh keinginannya sendiri, karena ia diseret dan dipikat olehnya. Dan apabila keinginan itu telah dibuahi, ia melahirkan dosa; dan apabila dosa itu sudah matang, ia melahirkan maut. Saudara-saudara yang kukasihi, janganlah sesat!" (Yakobus 1:14-16)

\section{Mengalahkan Pekerjaan Pencobaan Iblis}

Memahami cara kerja pencobaan sangatlah berguna, tetapi yang lebih penting adalah mengetahui langkah-langkah khusus yang perlu Anda ambil untuk mengalahkannya.

\section{Jangan mau diintimidasi}

Banyak orang Kristen dibuat takut dan hilang semangat oleh pikiranpikiran yang menghasut, dengan merasa bersalah karena mereka berada "di dalam" jangkauan pencobaan. Mereka merasa malu hanya karena terkena pencobaan. Inilah kesalahpahaman tentang kedewasaan. Anda tidak akan pernah bertumbuh tanpa pencobaan. Di satu sisi Anda bisa menganggap pencobaan sebagai suatu pelengkap. Iblis tidak perlu mencobai orang-orang yang sudah melakukan kehendaknya yang jahat; mereka sudah menjadi milik Iblis. Pencobaan adalah tanda bahwa Iblis membenci Anda, bukan tanda kelemahan atau sifat keduniawian Anda. Pencobaan juga merupakan bagian yang normal dari hidup manusia dan dari kehidupan dalam sebuah dunia yang berdosa. Jangan terkejut atau kecil hati karenanya. Bersikaplah realistis dengan kenyataan tak terhindarkannya pencobaan; Anda tidak akan pernah dapat menghindari sepenuhnya. Alkitab mengatakan, "Pada waktu kamu dicobai," bukan jika. Paulus menasihati, "Pencobaanpencobaan yang kamu alami ialah pencobaan-pencobaan biasa, yang tidak melebihi kekuatan manusia." (lKorintus10:13). Dicobai bukanlah sebuah dosa. Yesus dicobai, tetapi Dia tidak pernah berbuat dosa (Ibrani 4:15). Pencobaan menjadi dosa hanya bila Anda menyerah padanya. Martin Luther mengatakan, "Anda tidak bisa mencegah burung untuk terbang di atas kepala Anda, tetapi Anda bisa mencegah mereka membangun sarang di rambut Anda." Anda tidak bisa mencegah Iblis untuk mengajukan pikiranpikiran, tetapi Anda bisa memilih untuk tidak memikirkannya atau bertindak berdasarkannya. Misalnya, banyak orang tidak mengetahui perbedaan antara rasa terpikat fisik atau gairah seksual dengan hawa nafsu. Hal-hal tersebut tidak sama. Allah menjadikan kita semua sebagai makhluk seksual, dan hal itu baik. Rasa terpikat dan gairah merupakan tanggapan pemberian Allah yang bersifat alami dan spontan terhadap keindahan fisik, sementara hawa nafsu merupakan tindakan kehendak yang disengaja. Hawa nafsu merupakan pilihan untuk memikirkan apa yang ingin Anda 
lakukan dengan tubuh Anda. Anda bisa terpikat atau bahkan tergairahkan tanpa memilih untuk berdosa dengan hawa nafsu. Banyak orang, terutama laki-laki kristen,merasa bersalah karena hormon-hormon pemberian Allah mereka bekerja. Ketika mereka secara otomatis melihat seorang wanita yang menarik, mereka menganggap itu hawa nafsu dan merasa malu serta bersalah. Tetapi rasa terpikat bukanlah hawa nafsu sebelum Anda mulai memikirkannya. Sesungguhnya, semakin dekat Anda kepada Allah, semakin gencar Iblis berupaya mencobai Anda. Saat Anda menjadi anak Allah, Iblis yang bagaikan penjahat memukul manusia, membuat suatu "kontrak" untuk Anda. Anda merupakan musuhnya dan dia merencanakan kejatuhan Anda. Kadang-kadang sementara Anda sedang berdoa, Iblis akan mengajukan sebuah hal aneh atau pikiran jahat hanya untuk membingungkan Anda dan membuat Anda malu. Jangan takut atau malu karena ini, tetapi sadarilah bahwa sebenarnya Iblis takut terhadap doa-doa Anda dan akan mencoba segala upaya untuk menghentikannya. Daripada menyalahkan diri sendiri dengan "Bagaimana saya bisa memikirkan hal-hal semacam itu?" lebih baik menganggapnya sebagai gangguan Iblis dan segera pusatkan pikiran kembali kepada Allah.

Kenali pola pekerjaan Iblis dan bersiaplah menghadapinya

Ada situasi-situasi tertentu yang membuat Anda lebih rentan terhadap pencobaan daripada orang lain. Beberapa situasi akan membuat Anda tersandung dengan cepat; sementara yang lainnya tidak begitu mengganggu Anda. Situasi-situasi ini unik bagi kelemahan Anda dan Anda perlu mengenalinya karena Iblis pasti mengenalnya! Iblis tahu persis apa yang membuat Anda tergelincir, dan dia terus-menerus bekerja untuk memasukkan Anda ke dalam situasi-situasi itu. Petrus memperingatkan, "Sadarlah dan berjaga-jagalah! Lawanmu, si Iblis, berjalan keliling sama seperti singa yang mengaum-aum dan mencari orang yang dapat ditelannya." (1Petrus 5:8). Tanyakan diri Anda sendiri, "Kapankah saya paling sering dicobai? Hari apakah? Jam berapa?" Tanyakan, "Di mana saya paling sering dicobai? Di tempat kerja? Di rumah? Di rumah tetangga? Di tempat olah raga? Di bandara atau rumah penginapan di luar kota?" Tanyakan, "Siapa yang bersamaku ketika aku paling sering dicobai? Teman? Rekan sekerja? Sekelompok orang asing? Ketika saya sendirian?" Juga tanyakan, "Bagaimana biasanya perasaan saya ketika saya paling banyak dicobai?" Mungkin ketika Anda lelah atau kesepian atau bosan atau sedih atau tertekan. Mungkin ketika. Anda terluka perasaan atau marah atau khawatir, atau setelah sebuah keberhasilan besar atau kesuksesan rohani. Anda perlu mengenali pola khas pencobaan Anda dan selanjutnya bersiap untuk menghindari situasi-situasi tersebut sebanyak mungkin. Alkitab secara berulang-ulang menyuruh kita untuk mengantisipasi dan siap menghadapi pencobaan (Matius 26:41; Efesus 6:10-18; 1Tesalonika 5:6,8; lPetrus $1: 13 ; 4: 7 ; 5: 8$ ). Paulus berkata, "dan janganlah beri kesempatan kepada Iblis" (Efesus4:27). Perencanaan yang bijak mengurangi pencobaan. 
Ikutilah nasihat Amsal: "Tempuhlah jalan yang rata dan hendaklah tetap segala jalanmu. Janganlah menyimpang ke kanan atau ke kiri, jauhkanlah kakimu dari kejahatan." (Amsal 4:26-27) "Menjauhi kejahatan itulah jalan orang jujur; siapa menjaga jalannya, memelihara nyawanya." (Amsal 16:17).

\section{Mintalah pertolongan Allah}

Surga memiliki saluran gawat darurat dua puluh empat jam. Allah ingin Anda meminta pertolongan-Nya untuk mengatasi pencobaan. Dia berkata, "Berserulah kepada-Ku pada waktu kesesakan, Aku akal meluputkan engkau, dan engkau akan memuliakan Aku." (Mazmur 50:15) Saya menyebutnya doa "microwave" karena cepat dan langsung pada pokok masalah: Tolong! SOS! Mayday! Ketika pencobaan menghantam, Anda tidak punya waktu untuk percakapan yang panjang dengan Allah; Anda hanya berseru. Daud, Daniel, Petrus, Paulus, dan jutaan orang lain pernah menaikkan jenis doa yang cepat ini untuk meminta pertolongan di dalam kesulitan. Alkitab menjamin bahwa seruan kita untuk meminta bantuan akan didengar karena Yesus peduli pada pergumulan kita. Dia menghadapi pencobaan-pencobaan yang sama seperti kita. "Sebab Imam Besar yang kita punya, bukanlah imam besar yang tidak dapat turut merasakan kelemahankelemahan kita, sebaliknya sama dengan kita, Ia telah dicobai, hanya tidak berbuat dosa." (Ibrani 4:15). Jika Allah terus menanti untuk menolong kita mengalahkan pencobaan, mengapa kita tidak berpaling kepada-Nya lebih sering? Secara jujur, kadang kita tidak ingin ditolong! Kita ingin menyerah pada pencobaan sekalipun kita tahu itu salah. Pada saat itu kita mengira kita lebih mengetahui apa yang terbaik bagi kita daripada Allah. Pada saatsaat lain kita malu untuk meminta Allah menolong karena kita tetap menyerah pada pencobaan yang sama berulang-ulang. Tetapi Allah tidak pernah menjadi marah, bosan, atau tidak sabar bila kita tetap kembali kepada-Nya. Alkitab mengatakan, "Sebab itu marilah kita dengan penuh keberanian menghampiri takhta kasih karunia, supaya kita menerima rahmat dan menemukan kasih karunia untuk mendapat pertolongan kita pada waktunya." (Ibrani 4:16) Kasih Allah abadi, dan kesabaran-Nya tetap selamanya. Jika Anda harus berseru meminta pertolongan Allah 200 kali sehari untuk mengalahkan pencobaan tertentu, Allah akan tetap dengan senang hati memberikan rahmat dan kasih karunia, jadi datanglah dengan berani. Mintalah kepada-Nya kuasa untuk melakukan hal yang benar dan kemudian berharaplah bahwa Dia memberikannya. Pencobaan-pencobaan membuat kita bergantung kepada Allah. Sama seperti akar bertumbuh makin kuat ketika angin bertiup menerpa sebuah pohon, begitu juga setiap kali Anda menghadapi sebuah pencobaan, Anda menjadi lebih serupa dengan Yesus. Ketika Anda tersandung, yang akan Anda alami pasti tidaklah fatal. Sebaliknya daripada menyerah, pandanglah pada Allah, harapkan Dia untuk menolong Anda, dan ingatlah akan upah yang sedang menanti Anda: "Berbahagialah orang yang bertahan dalam pencobaan, sebab 
apabila ia sudah tahan uji, ia akan menerima mahkota kehidupan yang dijanjikan Allah kepada barangsiapa yang mengasihi Dia." (Yakobusl:12). ${ }^{34}$

\section{PENUTUP}

\section{Kesimpulan}

Berdasarkan penguraian penulis dalam tulisan ini maka dapat ditarik kesimpulan sebagai berikut: Pertama, Dalam bagian pemahaman tentang Injil Sinoptik dijelaskan secara latar belakang tentang penulis ke tiga Injil tersebut. Kedua, Dalam bagian pemahaman Injil Sinoptik dijelaskan secara latar belakang masing-masing ketiga Injil tentang maksud dan tujuan penulis. Ketiga, Dalam bahagian pemahaman Injil Sinoptik dijelaskan tentang pengertian Injil dan Injil Sinoptik. Keempat, Dengan tegas Injil Sinoptik menjelaskan tentang Iblis. Walupun ada orang Kristen yang tidak menerima kebenaran ini. Namun tidak dapat diragukan lagi bahwa kitab Injil Sinoptik sangat jelas membicarakan Iblis dan roh-roh jahat. Kelima, Khususnya dalam konsep Injil Sinoptik sangat nyata bagaimana pekerjaan Iblis diuraikan dengan, mencobai, melalui fikiran manusia, merasuki tubuh manusia, membuat penyakit, menggunakan posisi, menggunakan waktu yang baik, serta menawarkan kemegahan dunia. Keenam, dalam Injil Sinoptik sangat jarang dibahas mengenai Iblis secara spesifik. Tetapi kegiatan atau pekerjaanya yang dilakukan sungguh ada dan jelas. Ketujuh, Dalam bagian pemahaman tentang Iblis di jelaskan, dengan fakta-fakta yang ada dalam pandangan atau konsep Alkitab tentang iblis dalam Injil Sinoptik. Kedelapan, Dan dalam bahagian pemahaman tentang Iblis juga dijelaskan bagaimana cara iblis mempengaruhi orang melalui pikiran dan bahkan roh-roh jahat merasuki orang hingga menjadi gila. Kesembilan, Iblis semata-mata hanya melakukan kejahatan dengan tipu muslihatnya, serta membuktikan keberadaanya kepada manusia. Kesepuluh, Semua orang yang belum percaya kepada Yesus Kristus dan belum lahir baru, ada dibawah kuasa iblis dan agen-agennya. Oleh sebab di luar Gereja Yesus Kristus adalah milik iblis. Kesebelas, Orang yang dikuasai iblis telah dibutakan rohaninya dan berada dalam hukuman Allah. Keduabelas, Khususnya dalam konsep Injil Sinoptik sangat nyata bagaimana pekerjaan Iblis diuraikan dengan, mencobai, melalui fikiran manusia, merasuki tubuh manusia, membuat penyakit, menggunakan posisi, menggunakan waktu yang baik,

\footnotetext{
${ }^{34}$ Rick Warren, The Purpose Driven Life (Kehidupan yang Digerakkan oleh Tujuan) (Malang:Gandum Mas 2004) Halaman : 223-228
} 
serta menawarkan kemegahan dunia. Ketigabelas, Iblis mempunyai kuasa yang besar, ia sangat licik dan pandai. Ia berusaha menyeret manusia ke dalam penjara dosa sehingga hubungan dengan Tuhan menjadi terpisah dengan berbagai macam yang Iblis lakukan.

\section{Saran-Saran}

Adapun saran-saran yang penulis kemukakan sehubungan dengan tinjauan teologis tentang Iblis dalam Injil Sinoptik adalah: Pertama, Setiap orang percaya perlu mengingat bahwa kitab Injil Sinoptik menjelaskan tentang iblis. Pertama kali Iblis dalam Injil Sinoptik mencobai Yesus sebanyak tiga kali, tetapi Iblis tidak mampu menyeret Yesus ke dalam rayuan Iblis, berarti Iblis memiliki kuasa tetapi yang sebenarnya Allahlah yang berkuasa atas segala kuasa yang ada di bumi ini maupun di luar bumi ini. Kedua, Sebagai seorang Kristen yang sudah telah diselamatkan, sepatutnyalah kita melihat apa yang dilakukan Yesus dan perlu kita teladani bagaimana seharusnya sikap kita bila menghadapi musuh-musuh terutama terhadap iblis. Ketiga, Sebagai orang percaya yang ada di dalam Kristus, kita telah diberi kuasa atas setan, sebagaimana Murid-murid Tuhan Yesus diberi kuasa atas setan, jadi orang percaya didalam Yesus Kristus dimampukan mengusir kuasa atas setan. Keempat, Sebagai orang Kristen yang memahami akan pekerjaan Iblis, hendaklah serahkan seluruh hidupmu kepada-Nya dan mintalah pertolongan hanya kepada Tuhan, berdoa dan serta berpuasa agar iblis tidak dapat mencobai atas seizin Allah.

\section{DAFTAR PUSTAKA}

Buku

A. Jhon Mcmillan, Perjuangan Melawan Kuasa Kegelapan, (Malang: Gandum Mas, 1984)

Dr. Kurt Koch,Occoult ABC, Literature Mission Aglasterhausaen Inc, Germany, tahun 1980

Ensiklopedi Alkitab Masa kini jilid I A-L (Jakarta: Yayasan Komunikasi Bina Kasih OMF, 1992)

F. Budi Hardiman, Filsafat Modern Dari Machiavelli sampai Nietzsche. (Jakarta: PT Gramedia Pustaka Utama, 2004)

Martin R. De Haan II, Iblis Di dalam Kegelapan (Yokyakarta : Yayasan Gloria) 
Pdt. Dr. E.P. Gintings, Drs. Djorelit Surbakti, Maria Br. Ginting, Okultisme, (Bandung : Bina Media Informasi)

Rick Warren, The Purpose Driven Life (Kehidupan yang Digerakkan oleh Tujuan), ( Malang:Gandum Mas 2004)

Scan Balawin, Permainan Iblis (Bandung : Kalam Hidup)

W.E, Vine, Expository Of New Testament Word, Zondervan Publishing House, Michigan, tahun 1952,hal.340.

William W. Orr, Setan Ada atau tidak?, (Bandung: Yayasan Kalam Hidup, 1970)

William W.ORR,Misteri Iblis,(Bandung : Kalam Hidup)

\section{Internet}

"5. Gayahidup Penginjil", diakses tanggal 25 mei 2008; tersedia di http:// www.dci.org.uk.

"Ringakasan Khotbah, di akses tanggal 25 mei 2008: tersedia di http://www. Griis. Org / ringkasan khotbah / 2004 / 20040627. htm.

By Dr. Paul Sene, Membuka Topeng Strategi Musuhmu. Diakses 24 mei 2008; tersedia di http:// H Iblis dalam markus. Htm.

Dr.R.L. Hymers, Jr. "khotbah" diakses tanggal 25 mei 2008; tersedia di http://www.realconversion.com.

"Pola Iblis [043]". Diakses 25 mei 2008; tersedia dihttp://www.logon.org dan http://www.ccg.org.

webmaster@sabda.org.

www.Solar-Aid.org. 